\title{
HIGH TREASON. THE ACTIVITY OF THE COMMUNIST PARTY OF WESTERN BELARUS IN VILNIUS IN 1930-1935
}

\author{
SERGIUSZ ŁUKASIEWICZ \\ noffres@gazeta.pl \\ University of Wrocław \\ Poland
}

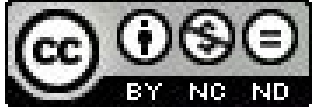

\begin{abstract}
The purpose of this paper is to attempt to explain the activities of the Communist Party of Western Belarus in Vilnius during the first half of the thirties of the twentieth century. The author's aim is to show the organisation, theory and practice of this illegal party. Furthermore, the intention is to present the activities of Vilnius police towards communist sympathizers and activists. Founded in 1923 in Vilnius, the Communist Party of Western Belarus was a branch of The Communist Party of Poland. This organization like the polish communist party was illegal. Its aim was to combat the Polish state and to perform electioneering for the Union of Soviet Socialist Republics. Although the name of the party could indicate a desire for independence of Belarus, in practice it was for the removal of the north eastern provinces of the Second Republic of Poland to the USSR. CPWB activity had a special dimension in Vilnius. As the region's largest city and former capital of the Grand Duchy of Lithuania, Vilnus was home for many nations, religions and cultures. Moreover, Vilnius was the most important field for communist action. Given the number of inhabitants, industrialized multi-ethnic character, communists had the opportunity to develop wide subversive and conspiratorial work. In addition, the city was the great centre of production and distribution of communist publications, which allowed the spread of propaganda in both its administrative boundaries and in the Vilnius Voivodeship.
\end{abstract}

Key words: communism, Second Polish Republic, Communist Party of Western Belarus, Vilnius, State Police, Vilnius Voivodeship

\section{PREFACE}

The aim of this article is to reflect upon the activity of the Communist Party in Vilnius in the first half of the third decade of the 20th century. The research for this paper, has been supported by archive materials and data collected at the Central Archives of Modern Records in Warsaw (CAMR) and at the Lithuanian Central State Archives in Vilnius (LCSA). The following article is mainly based on: police files, administrative records and the communist movement's confidential archives.

The Second Polish Republic pursued repressive policy towards the communist movement. So did the Polish authorities within Vilnius, which along with Lviv, was considered one of the most significant cities on the map of eastern voivodeships. Nevertheless, it has to be emphasized that the fight between the illegal com- 
munist movement in Vilnius and the national police services was exceptionally fierce. The reason being the local awareness of Bolshevik reality in the period from 1919 to 1920 and The Communist Party of Western Belarus' political program, which stated a need to separate Vilnius from the Polish Republic. As a consequence, the choice of the communists' political program not only related to opting for soviet rule, like in other areas of the country, but to high treason as well.

\section{POLITICAL CRIME IN THE SECOND POLISH RePUbliC}

Political delinquency was thoroughly regulated via Makarewicz code (1932), which was the crowning of the attempts of codification of several penal systems within the Republic since 1918. It is relevant to quote some of the references in order to prove that legal norms were not abided by both the Polish and Lithuanian communists within their political activity. Penal code named political offences as follows :

- State crimes - punished by a minimum of 10 years imprisonment or capital punishment in more severe cases.

- Spying and some of the crimes threatening the state - arrest for up to 10 years. In the event of an unintentional offence the offenders would have faced up to 3 years under arrest.

- Crimes against the government and state offices - ranged from 3 to 5 years spent in high security prison.

- Crimes against public order - 5, up to 10 years of imprisonment (Makarewicz 1932, p. 226-228).

\section{VILNIUS'S ROLE IN SEDITION}

Communist materials as well as the home police reports revealed that Vilnius, under every account, was a perfect area in which to run underground activities. The communists were capable of taking advantage of social, religious and national classifications (LCSA, f. 51, vol. 1150, p. 80). In 1931, the former capital city of the Grand Duchy was inhabited by 195000 people. Amongst them, 67000 lived off coal mining and industry. Out of those 11000 people worked at medium and well-developed establishments. Vilnius used to be inhabited by 128000 Poles, 54000 Jews, 7000 Russians and by 1700 Belarusians. Those, however, are unofficial numbers, which do not include the ethnic minorities of Ukrainians, Czechs, Germans and Lithuanians. There were 60-70 working trade unions (Skład główny w Centralnym Biurze Statystycznym Miasta Wilna 1938, p. 155).

Because of the economic crisis, Vilnius at that time was a particularly attractive area for party activities. In 1931, soon after 14000 workers had been made redundant, the rate of unemployment rocketed to 24440. Up until 1934, another 3000 blue-collar workers had lost their jobs. It was not until 1935, that the unemployment dropped to its previous level from 1931. The enterprises that managed not to collapse were haunted by employee's strikes. There were only ten strikes that took place in 1931, in which 1200 employees took part, as opposed to 31 strikes organized in 1934. Over 5600 labourers participated in the protest; there were 
more than 500 different-sized work establishments, which discontinued working as an expression of their opposition against the then current situation. Furthermore, other companies reduced the length of shifts, which only made daily existence even more of a struggle (Skład główny w Centralnym Biurze Statystycznym Miasta Wilna 1938, p.1 55). It would appear that economic and social difficulties enabled The Communist Party of Western Belarus (CPWB) to expand the operations of increasing their influences in a city going through economic crisis. The communists had an opportunity to gain popularity amongst the crowd.

One should presume that Vilnius, as the biggest urban centre of the region, was undisputedly a heart of sedition. The size of the city and its diversity could obviously work in favour of hiding both illegal and underground activities. Thanks to wide contacts and party rooms it was possible to produce and send directives, advice and propaganda materials to the province.

From a communist point of view, Vilnius's conditions were not destitute of significant obstacles preventing underground activities. As the administrative centre of the region, Vilnius was the biggest concentration of police services, which were perfectly aware of communist activity taking place. Furthermore, amongst 195000 residents, 128000 Poles were not given many reasons to support an illegal party which considered the local authorities the occupant. Obviously, there were some communists amongst the Polish residents; however, they were a minority. For those political and national reasons, The Communist Party of West Belarus had 2/3 of the inhabitants against it. Lack of the political support from the majority of the Poles did not work in favour of running communist activities. In that case, it seemed essential to base the whole organisation scheme on Russians, Belarusians and Jews. However, one has to notice that amongst 67000 of the rest of the residents, a majority of them had a negative attitude towards Bolshevism. In reality, The Communist Party of West Belarus's foundations were a small percentage of Belarusians and the Jewish youth, which in a way did not fit into the Bund (Śleszyński 2007, p. 281). To politically active Jews, supporting The Communist Party of Western Belarus or a nationally oriented party, was the most common choice (Śleszyński 2007, p. 282). However, it has to be emphasised that the local Jewish community, was mainly conservative and Zionist (Śleszyński 2007, p. 280). What is more, pro-Bolshevik attitudes of the non-Polish part of Vilnius derived from the Russian cultural legacy(Śleszyński 2007, p. 280). Moreover, residents of the age of 40 or older were very few and they would leave the practical activities in the hands of the young (LCSA, f. 51, vol. 1150, p. 67).

\section{THE COMMUNIST PARTY OF WESTERN BELARUS}

The appointment of The Communist Party of Western Belarus operating in Białystok, Polesie, Novogrod and Vilnius province, was decided by the resolution of the $2{ }^{\text {nd }}$ Convention of The Communist Party of Poland(CPP) in August 1923. Finally, the communist group was formed in October 1924, absorbing all of the communist organisations, present in the north-eastern voivodeships (Bergman 1984, p. 12). Thanks to including the Belorusian Revolutionary Organisation or Belorusian Socialist Party, both very popular amongst farmers, towards the end of the first year there 
were 2500 members (Iwaniuk 2008, p. 1). 60-80\% of them were Belarusian (Schatz 1991, p. 96), the remaining members were Jewish, Polish and Ukrainian (Cimek 2009, p. 14). In the same year the youth section of the party known as The Belarusian Communist Youth Union (BCYU) was created.

$C P W B$, just as the Communist Party of Western Ukraine (CPWU), came to be, as the autonomic unit inside the $C P P$. Its social and economic program was almost identical to the mother party, depicted by imposing communist dictatorship similar to the one in USSR. Apart from the necessity to change the political system, one stressed the importance of improving on serfs' and blue- collar workers' work standards and an urge to land nationalization and other forms of properties. In the $C P W B$ rhetoric these issues were additionally nationally tinted. Ever since the second rally in November 1924, one opposed for "self-determination until separation" (Kowalski 1966, p. 324-326) of the territories from east of the Curzon line. This was meant to come into being through the revolution supported by the Red Army (Śleszyński 2007, p. 258). After the revolution, the north-eastern area of Poland was going to be included in the Byelorussian Soviet Socialist Republic (Garlicki 1999, p. 163). The main task of CPWB was to prepare their own activists and working class for the coming social and national "liberation". The last question was a manipulation, it was only a meant to introduce the Soviet regime (Reguła 1994, p. 262). Also as a preparation for the revolution CPWB was trying to internally destabilize the regions and weaken the defensive abilities of the Polish state. The number of $C P W B$ members was not threatening as opposed to the social implications of their programme, which was not to be disregarded. The cultural and religious proximity of soviet Russia accompanied by mistakes of the local administration allowed the maintenance of the stable level of support amongst the Belarusian peasants (Śleszyński 2007, p. 258).

From the very beginning $C P W B$ along with $C P P$ and $C P W U$ was an illegal organisation, whose seditious activity acted against state interest. Just like other organisations $C P W B$ was fully dependant on the USSR. It was a tool for fulfilling the guidelines of Comintern (Śleszyński 2007, p. 259) aiming at destabilizing north-eastern provinces.

\section{THE PRACTICAL ASPECTS OF VILNIUS' COMMUNIST ACTIVITIES}

The Communist Party of Western Belarus consequently tried to undertake actions against the Polish government and at the same time exposing the reality of the soviets in bright colours. During their day-to-day activities, the communists used a wide array of slogans regarding freedom, equality, goodwill, breaking up of land, liberties, education and culture in native language. It was in their mindset to expose any administrative irregularities as well as using the tension between the nationalities occupying the state, especially the city of Vilnius (LCSA, f. 51, vol. 1150, p. 21).

The Polish government was denounced against all the issues, particularly, anything of an economic nature. The topic of membership of Northern provinces to The Polosi Republic was not mentioned in a different light, as was the one 
about the West Belorussia occupation. The most often used terms describing the enemy were: "fascism", "white terror". At the same time, the party was portrayed as a group under constant repression. $C P W B$, according to its own propaganda, was fighting for social and historic fairness. Consequently, it positioned itself as a national - liberation movement. These were the topics mentioned more often than overthrowing the capitalistic structure (LCSA, f. 51, vol. 1150, p. 46). In the work of Vilnius party there was a separate role for the Lukiškès Prison. The party's propaganda described it as the place of the worst repression, often calling it "fascist terror" (CAMR, f. 1182, vol. 10, p. 6).

The complete operations of the party were conducted under cover. There were great opportunities in the city to conspire, prepare and distribute materials and cover up of various items as well as communist contributors. $C P W B$ could exploit the size of the city, allowing for better success in hiding any kind of forbidden items as well as people before the investigating services. Besides, the largest concentration of industries on the provided land - the north - eastern part, was providing a chance to connect with the workers in the area, consequently leading to huge gains in votes on both, political and financial levels (LCSA, f. 51, vol. 3023, p. 91).

The Party's conferences were held at specific, local sites. Often, they were rented apartments. It was rare to see such conferences in more exposed spaces or among the crowds on the streets. The party members, who were engaged in conspiracy, had to use their confidential code language to communicate with the other party members. Much effort was put into organizing huge meetings. The meetings of superiors with regular party members were limited. The meetings were usually held in the late evening or during the night. The communication within the city was organized by way of couriers, who would transfer the information and propaganda materials. The role of party's instructors was even more important as they were sent into the field with a goal to smooth out the operations in the region (LCSA, f. 51, vol. 3023, p. 93).

Excluding the connection centres, there were also party magazines as well as secret printing houses. In the former, the propaganda materials were held as well as mail, magazines or signs. In the latter, there was a special machine allowing for huge printing output of the materials for the city and surrounding areas. The members of the party, in case of loss of access to the premises, were still able to function. The propaganda materials were then hidden in basements or attics of private apartments (LCSA, f. 51, vol. 3023, p. 78). They also fulfilled a function of a meeting space in case there was no other alternative.

In addition, there was a party intelligence office, whose objective was to spy on the investigation services as well as suspected members of the party and then getting rid of any members who had any connections with the police. In at least a few cases, CPWB sentenced some of its members to a death row (CAMR, f. 1182, vol. 20, p. 2). It is known that the party spied on a police agent even after few years of him quitting the police force. The communists were also defending against infiltration by spreading rumours, saying that every confidant would have to stand trial as witness, and that would lead to instant disclosure of the party member's identity (Śleszyński 2007, p. 258). 
The actions of $C P W B$ were augmented during special Jewish and Christian holidays, when the anti-religion actions were on the rise. However, the most important field where the communist presence could be expressed was the anniversary of the beginning of the October Revolution and World War I. Also, the International Mother's Day and International Day of Helping Revolutionists were playing huge role in the party's calendar. The day of 1st of May also had special place in their calendar (Śleszyński 2007, p. 263-265). However, it is worth mentioning that the State Police was completely aware of the communists moves (Śleszyński 2007, p. 264), consequently, organizing any movement during these holidays was specifically difficult for the communist activists (Awantura w sali miejskie 1934, p. 2). These activists were aware of that and tried to blend in into socialist manifestation and then distribute their propaganda material, shout revolutionary slogans and radicalize the crowds. Police had complete freedom in using force and they were often found to be abusing this freedom.

The funds for the everyday running of the party were gained from subvention of the Central Committee (CC) as well as from membership fees, which accounted for nearly $15 \%$ of the funds. It was often the case that different organizations backed up the party including the 1934 injection of funds from Jewish Theatre of People (LCSA, f. 51, vol. 1150, p. 45). In 1930, the monthly budget totalled $3300 \mathrm{z}$. Most of the funds were transferred to actions undertaken within the city limits of Vilnius, mostly technical, which consumed around $600 \mathrm{zł}$. The second group of expenditures was upholding of the party. The city's secretary was receiving compensation in the sum of $150 \mathrm{zl}$, the same amount as was dedicated to the party's instructors, who distributed propaganda materials to different regions (LCSA, $\mathrm{f}$. 51, vol. 1150, p. 77).

Allocations of larger sums for communist materials printing allowed for the creation of large quantities of such materials. In 1930, 137 different flyers were printed in numbers exceeding thousands of issues (LCSA, f. 51, vol. 1150, p. 85).

Besides propaganda other activities included agitation targeting regular workers, farmers, unemployed and service men, demonstrations during celebrations of a holidays as well as protests against the politics of the government which were a priority for the party. Because larger assemblies organized by communists were usually shut down by State Police, in 1930 the party put its efforts into organizing a group of 60 people as a "self-defense" group, whose main objective was to be a paramilitary. However, the induction of new members into communist militia was insignificant, consequently leading to organizing only 30 people in January 1931 to defend CPWB. The gathered members did not represent CPWB as they were cowards, and were first to run at the sight of State Police. In addition, this unit lacked any workshop workers or people from outside the party (LCSA, f. 51, vol. 1150, p. 85). Any efforts to restructure the unit had no significant improvements; no sources mention the unit in the years to come.

After first convention of the CPWB, which took place in July 1928 in Soviet Belorussia, the communists changed their tactic. Diversion and sabotage was meant to be replaced by efforts to take over as much of the social and political scene as possible through communist organizations (W. Połujan., I. Połujan 1962, p. 77). 
Between 1930 and 1935, CPWB was taking care of wide variety of activities. They were expanding their propaganda within factories of various sizes, educational organizations, army, unions as well as the unemployed and the army reserve. Often, propaganda campaigns were held in the name of anti-war movement, anti-government and anti-religion, however, the main idea of some of them was to glorify the USSR. The party was also visible during the elections. A constant feature of their actions was to organize protests against the politics in the Lukiškès Prison, which was seen by the city communists as a place of executions (CAMR, f. 1182, vol. 20, p. 14).

Based on the available sources, it was confirmed that the biggest successes $C P W B$ ever achieved were in its work with youth. Their natural eagerness to contest reality and their idealism was used for communist agitation (Śleszyński 2007, p. 265). Huge propaganda action was underway in the young Jewish and Belarusian community. In some places, communist agitation amongst youth was up to 500 people (LCSA, f. 51, vol. 1150, p. 67). In comparison to the scale of activities of $B C Y U$, the activity in the workers field posed greater obstacles. Although the advocates or members of the $C P W B$ were even in the famous institution Elektrik, they were unsuccessful, surrounded by distrust from the workers. In addition, no major achievements in the military were noted. In the recruitment revolutions organized by BCYU, up to 80 people were involved (LCSA, f. 51, vol. 1150, p. 81).

Vilnius organization was divided between two neighbourhood committees Nowe Zabudowania and Łosiówka. Divisions called "jaczejki" fell under these committees, and they had variable numbers largely due to a rotation of members and arrests. For example, in 193118 "jaczejki" existed, which included 4 Poles, 20 Belarusians and 70 Jews. Besides them, there were divisions of BCYU and International Red Aid (IRA). The structure of organization was unstable because of the regular changes of the organization itself and various activities of the State Police, which often paralyzed whole conspiracy organization (LCSA, f. 51, vol. 1150, p. 71).

As the information exchange between members of the party indicates, The Vilnius organization showed huge involvement and variety of tasks undertaken. However, Central Comittee criticized it for the lack of success on the industrial scene, low level of literature output and inability to control the biggest unions as well as insufficient punishment and conspiracy of local divisions (LCSA, f. 51, vol. 1150, p. 74).

\section{INVESTIGATING VILNIUS' COMMUNIST ENVIRONMENT BY STATE POLICE}

CPWB was a significant object of Vilnius's police interest (Śleszyński 2007, p.266). Even though, within 1928 -1933, the number of police officers had been decreased from 640 to 515 (Skład główny w Centralnym Biurze Statystycznym Miasta Wilna 1938, p. 155), it did not result in reducing the efficacy of fighting the CPWB. Apart from frequent pacifications and mass arrests, the fundamental role was played by secret services. Based on the materials available, an activity run by 40 informants has been confirmed to have taken place in that period of time. It is disputable how many of 
them worked within Vilnius (LCSA, f. 1150, vol. 3022, p. 1), nevertheless, even if they did work within the city, their party environment and political activity would still allow them come across Vilnius communists or local emissaries quite frequently. Informants' actions were quite often motivated by patriotic reasons or an urge to turn their back on the ideology of communism that they did allow themselves to support for some time (Reguła 1994, p. 6). It was not an unusual thing that the agents were often rewarded. Moreover, they could have counted on policy services and the administration's support and help. In the event of denunciation, they would have been provided with a job, time and identity change. What is more, if $C P W B$ were to take revenge, it would not hesitate to punish its betrayers with capital punishment and it that case the informants were provided with severance pay and a transfer to another voivodeship (CAMR, f. 1182, vol. 20, p. 2).

It was quite a common thing that police informants were of a higher standing within the party, e.g.: secret agent "Mosquito" a Regional Committee secretary (RC) Naujoji Vilnia (LCSA, f. 51, vol. 3021, p. 40). However, even though they were not in charge anymore, usually it was only their presence that was considered enough when gaining information that could enable others to unveil the identity of others engaged with $C P W B$ activities. Not only under the count of numbers was the infiltration of communist communities in Vilnius via State Police considerable, but frequent as well. The information provided by the agents was adequate enough to gradually prevent communist activities from taking place. On the other hand, the Vilnius communists' activity had never been completely eradicated, which implies remarkable viability of the organisation itself. Still, it was not enough for the communist party to continue working on their political assumptions and program. The less the $C P W B^{\prime}$ s members, the other ranks in particular, obeyed the ground rules of conspiracy, the easier it was for the state police and its informants to operate.

At times, the state police did not interfere in their activity. For instance, the activists looking for asylum in USSR were allowed to cross the border freely. It was believed, that by doing so, the party does not work in its own favour and, consequently, weakens and disorganises itself. Furthermore, one thought, that taking such an action, would make it even more of a struggle for the asylum seekers to force their way back through Vilnius (LCSA, f. 51, vol. 3023, p. 60).

The range of infiltration of $C P W B$ can be depicted by the events dating back from 1934. It would appear, that the biggest operation run by $C P W B$ took place in Vilnius, when the celebrations of 1st of August were to be organised. That day was considered the commencement of "Imperial War" in 1914 and an "anti-war day" as well. This is exactly when, on the pretext of pacifism and in memory of those events, the presence of communists in Vilnius was planned to be expressed (LCSA, f. 51, vol. 3023, p. 100).

Being extraordinarily cautious about staying in conspiracy, $C P W B$ had prepared itself to take its biggest actions for a few weeks. From $17^{\text {th }}$ of July there were party conferences that took place, mainly dedicated to the August events. Amongst the programs, there were jaczejeki's protests, banners and other communist materials to be propagated, obviously in the most visited and popular city 
spots (LCSA, f. 51, vol. 3023, p. 71). In order to gain as much as possible support of the independent people, the party members were constantly urged on in order to create an impression of "spontaneity" and "apolitical character" within the operation-taking place.

In order to create the greatest impact the operation of CPWB was coordinated with $B C Y U$. Ever since that moment, all the decisions were meant to be made jointly. In particular quarters, for instance small scale rallies were organised, for instance: in the train depot, the tobacco factory, the soap factory and local brickyards. Especially active, were the youth of $B C Y U$, which, only a few weeks preceding the operation from $1^{\text {st }}$ of August, had increased their ranks by a few dozens. While doing so, there was a priority to select a person skilled in oratory It was believed, that on $1^{\text {st }}$ of August, a speaker attracting the public's attention, may contribute to the action more successfully than by propagating the visual communist materials, such as banners or the fliers, itself (LCSA, f. 51, vol. 3023, p. 71).

Apart from anti - war slogans, the opposition against the existence of the German concentration camps and the defence of Ernst Thälmann (the leader of The Communist Party of Germany), were the main mottos of the protests. The communist side, strategically, assumed that giving the events the character of a demonstration against German totalitarianism, would appeal more to the demonstration's participants. As a result, more of ware people unaware of the CPWB were expected to participate in those events. On the last day of July, there was even some "shunting" planned in the secluded parts of the city, only to gauge the ability to communicate and commute one the operation starts (LCSA, f. 51, vol. 3023, p. 72).

Given previous experience, the action command, was in one person's hands only.

The commanding officer was required to devolve upon his local adjutants. However, they were still left with some autonomy within their acts. In the morning hours on $1^{\text {st }}$ of August, the main schedule of the event, such as the times of demonstrations and the main assumptions of the rallies, were meant to have been decided. To give some extra momentum to these events, the chosen members of the party, were required to especially campaign at the biggest industrial establishments. The aim of such behaviour was to cause some mayhem and strikes, or at least to lead to interruption and make workers break their shift in the event of a failure. Regardless, all the $C P W B$ members being in Vilnius on $1^{\text {st }}$ of August were entirely restricted from work. The youth and the pioneers were to protest separately. In case of a failure, there was an alternative plan based on organizing some smaller scale protests in all of the quarters, instead of organizing a single, large scale manifestation (LCSA, f. 51, vol. 3023, p. 87).

Arranging the August demonstration, $C P W B$ limited other activities and prioritised $1^{\text {st }}$ of August. In the last ten days of July, only four cases of communist literature propaganda and two cases of banner hoisting were stated. The decrease in party's activity hinted to the state services, the fact that there was a massive action to be arranged (LCSA, f. 51, vol. 3023, p. 89).

Nevertheless, the $C P W B^{\prime}$ s preparations were no secret to the state security services. Police services did refrain from taking more severe and serious actions, 
in order to collect as much data and information regarding names and addresses of the local communists first (LCSA, f. 51, vol. 3023, p. 90).

The counterattack took place on $25^{\text {th }}$ of July, when the local CPWB committee secretary, who monitored the operation preparations, had been arrested. The party agent, who was arrested, turned out to have used a fake passport under the name Paweł Gorelik, he also inhabited Vilnius illegally. So that the August operation paralysis could be continued, just before July came to an end, two stocks of the propaganda literature were seized and five people in charge of them were arrested. On 27 July, some more arrests took place, however, this time it was an interrupted attempt to hang banners out and the literature colportage. Only two days later, at around $1.00 \mathrm{pm}$, State Police stopped a meeting organized by IRA. Among the people participating in that meeting, over twenty were caught: some of the highly experienced party agents and a member of local committee of IRA. By the end of the month the district constables were arrested as well (LCSA, f. 51, vol. 3023, p. 110).

Those ones who were in charge of the leadership, who managed to get through those arrests, tried as they might to distance themselves. Moreover, as the police agents informed, there had been some attempts to conceal from the fellow comrades the fact that the leadership of the operation and the party environment had been prevented from completing their goals in the party environment. The reason was to maintain the morale of those members of CPWB who stayed at liberty. Still, some were some considered "happy”, about state police, accidents and the misfortune to the $C P W B$. One of these incidents is illustrated by one dating back to the 30th of July, when Franciszek Gajewski, a janitor who used to live at 36 Rydz-Śmigły Street, who discovered within the building a literature package prepared for colportage on 1 August. The hiding - place contained 680 proclamations. Unfortunately, to $C P W B$, Franciszek Gajewski, as a loyal member of the Nonpartisan Bloc for Cooperation with the Government (NBCG) immediately reported his finding. Three days before, in similar circumstances the inhabitant of a house by 16 Sofjaniki, Samuel Lichton, found at his attic 150 copies of proclamation written in Polish and Hebraic addressed to "the labours and youth working in Vilnius" (LCSA, f. 51, vol. 3023, p. 99).

In spite of the adversities experienced, the $C P W B$ did not discontinue their preparations, setting the very beginning of the operation on 1 August, at 5:45 pm. The people involved in the demonstration, were supposed to head the streets leading to Nowogródzki Market. There, two pigeons, to be girdled with red ribbons and set free at the specific times, were arranged to be a secret signal for those gathered there to enter the market. Additionally, at $8.00 \mathrm{pm}$, sharp at the intersection of Szeroka and Zawalna streets, another demonstration was to to begin. At the same time, police officers tried as well they discreetly could to inspire fear of defeat and exposure among the party activists (LCSA, f. 51, vol. 3023, p. 98).

Given the information mentioned above, which the State Police had access to, they decided to demonstrate and manifest police services' power. The frequency of police patrols increased, especially in the evenings. Intensified alertness of both the patrol and secret services was initiated. As a result, many activists were arrested (LCSA, f. 51, vol. 3023, p. 102). 
Even though, the "red pigeon" was set free precisely at $5.45 \mathrm{am}$, (what was interesting was that the sash he was girdled with, had written on its fabric: "Long live the international celebrations of fighting war of 1 August 1934"), there were only 20 participants gathered at the market. Moreover, half of them came as a group led by a police informant. The majority of people who, after all, did take part in the event, were the party members. As it was a clearly noticeable failure, the participants dispersed. Touched by a disgraceful failure, they disposed of any propaganda materials while making their way home. As police reported, there had been a package left on Mickiewicz Street, which contained 467 proclamations, and on Szeroka Street there had been a banner hung out, saying "Down with imperial war and assaulting USSR", there also had been 190 proclamations scattered in the streets (LCSA, f. 51, vol. 3023, p. 103).

Such a depiction is typical of the strategy of the running of its policy by the CPWB in Vilnius and the measures taken by the State Police. In spite of planning every move gradually, conspiracy commands and decentralisation, the Vilnius organisation was so thoroughly infiltrated, that just a few days of State Police's activities prevented the Vilnius' communist operation from taking place at 1 August. Bold planning failed and resulted in only 20 people turning up in the streets. Obviously, such measures were not enough to stabilise a situation in a populous city like Vilnius.

\section{RECAPITULATION}

In the light of presented materials the following conclusions arise. The Communist Party of Western Belarus wasn't able to take advantage of opportunities created by a great economic crisis. In spite of the obvious economic problems in Vilnius and of impoverishment of part of its population, the communists didn't record significant successes in the discussed period.

Apart from mistakes of activists consisting of the inept underground conspiracy and of the doctrinarism, which made it impossible for it to look realistic by force of their movement and its opponents, a significant role in curbing their influences was played by the Vilnius police officers and investigators. Although their communist adversaries constituted a small group, the State Police in Vilnius didn't ignore the CPWB activists. Thanks to that it constantly led to deep infiltration of municipal communist circles (CAMR, f. 2015, vol. 3, p. 71).

Thanks to the developed web of agents and the rather favourable attitude of the society, the State Police was able to work out $C P W B$ strategy to a considerable degree. It enabled gradual limiting of the subversive activities of communists, or often even nip them in the bud. What is more, the combination of mass arrests and deep infiltration of communists prevented the execution of programmed objectives of the $C P W B$.

This low effectiveness of communist activity in Vilnius also took effect in the province. Thanks to pacifying the municipal organization, maintaining the contact between the centre and periphery was much more difficult. Supplies of leaflets, appeals and other materials were being disrupted all the time. Directives and 
liaison officers from Vilnius, frequently didn't reach their destination. It often reached the situation, where local branches of $C P W B$, were forced to act on their own. However, without orders, and logistical and financial backup from Vilnius, effects of their actions were very slight. As a result, it led to further weakening of the communist movement.

To sum up, Vilnius organization in the discussed period was highly ineffective. The reach of communist influences was slight, especially amongst residents of Polish nationality. If necessary, the State Police was able to arrest the majority of active party members at any moment. It is necessary however to admit that in spite of such considerable police advantage, local authorities never managed to completely eradicate the communists activity in the city or to definitively break the contact with province and with Warsaw and the USSR. Therefore till the end of CPWB's existence, communists posed a threat to the safety of the city and the region.

\section{SOURCES}

Lithuanian Central State Archives in Vilnius (Lietuvos Centrinis Valstybés Archyvas) Fonds: Provincial Office in Vilnius (f. 51), Investigation Office in Provincial Headquarters in Vilnius (f. 1150),

The Central Archives of Modern Records in Warsaw (Archiwlim Akt Nowrch w Warszawie) Fonds: Communist Party of Western Belarus (f. 163), Provincial Headquarters in Vilnius (f. 2015), Provincial Office in Vilnius (f. 1182).

\section{BIBLIOGRAPHY}

Awantura w sali miejskiej (1934), „Słowo” 02.05.1934.

Bergman A. (1984), Sprawy białoruskie w II Rzeczypospolitej, PWN, Warszawa.

Cimek H. (2009), Problemy narodowościowe w Komunistycznej Partii Polski, [in:] R. Rauba (Ed.), Radykalna lewica na ziemiach polskich w latach 1893 - 1938. SDKPiL, KPRP,KPP, Druk - Ar, Zielona Góra.

Garlicki A. (1999), Encyklopedia historii Drugiej Rzeczpospolitej, Wiedza Powszechna, Warszawa.

Iwaniuk S. (2008), Prawdy i mity o KPZB, „Czasopis” 12.1.2008.

Kowalski J. (1966) Trudne Lata, Książka i Wiedza, Warszawa.

Makarewicz J. (1932) Kodeks Karny z komentarzem, Wydawnictwo Zakładu Narodowego Imienia Ossolińskich, Lwów.

Orłowska E. (1973) Pamiętam jak dziś, Książka i Wiedza, Warszawa.

Reguła A. J. (1994), Historia Komunistycznej Partii Polski w świetle faktów i dokumentów, Portal, Torun.

Savchenko A. (2009), Belarus: a perpetual borderland, Brill, Koniklijke.

Schatz J. (1991), The generation: the rise and fall of the Jewish communists of Poland, University of California Press, Oxford.

Skład główny w Centralnym Biurze Statystycznym Miasta Wilna (1938), Rocznik statystyczny Wilna 1936 rok, Wilno.

Śleszyński W. (2007), Bezpieczeństwo wewnętrzne w polityce państwa polskiego na ziemiach pótnocno-wschodnich II Rzeczpospolitej, Instytut Studiów Politycznych PAN, Białystok.

\section{NETOGRAPHY}

Нацыянальна-вызваленчы, сялянскі і рабочы рух у Заходняй Беларусі (National liberation, peasant and labour movement in western Belarus), http:/ / www.istoriya.org/belarus-history/52-zahodniaja-belarus/191-ruh.html, retrieved: 10.10. 2011. 